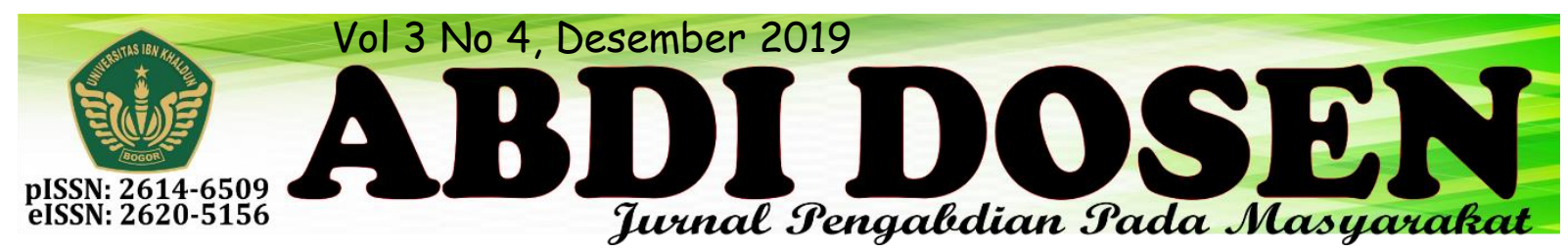

\title{
IMPLEMENTASI MODEL POLA MAKAN DAN OLAHRAGA PADA KELOMPOK PREDIABETES DALAM UPAYA PENCEGAHAN KASUS DIABETES MELLITUS DI ACEH BARAT
}

\author{
Enda Silvia Putri ${ }^{1}$, Arfah Husna ${ }^{2}$ \\ endasilviaputri@utu.ac.id ${ }^{1}$ \\ arfahhusna@utu.ac.id ${ }^{2}$ \\ Dosen Fakultas Kesehatan Masyarakat, Universitas Teuku Umar, Meulaboh, Aceh Barat ${ }^{1,2}$
}

\begin{abstract}
ABSTRAK
Prediabetes merupakan kondisi seseorang dengan kadar gula darah berisiko diabetes mellitus, namun belum dikategorikan diabetes mellitus. Berdasarkan data dari setiap Puskesmas di Aceh Barat Tahun 2018 yaitu Puskesmas Johan Pahlawan, Suak Ribe, Meureubo, Peureumeu Arongan Lambalek, Kaway XVI DM selalu menempati 10 penyakit PTM terbanyak, dan terutama yang menyumbang adalah daerah perkotaan. Gampong Kampung Belakang merupakan salah satu kampung yang menjadi wilayah kerja puskesmas johan pahlawan yang terletak di daerah perkotaan yang merupakan penyumbang salah satu kasus DM terbanyak. Berdasarkan hasil survey awal (Putri, dan Is, 2017) Gampoeng Kampung Belakang (40\%) penduduknya berada pada kelompok prediabetes disebabkan oleh gaya hidup (pola makan dan olahraga yang tidak sehat). Tujuan pengabdian ini adalah implementasi model pola makan dan olahraga pada kelompok prediabetes dalam upaya pencegahan kasus diabetes mellitus di Aceh Barat. Metode pengabdian adalah dengan melakukan pemicuan pola makan dan olahraga pada kelompok prediabetes dalam bentuk demo masak, olahraga, dan pemberian menu makanan anti diabetes yang diimplementasikan dalam tiga bulan. Hasil pengabdian mampu membentuk pola makan dan olahraga pada kelompok prediabetes, sehingga mampu mencegah diabetes. Kesimpulan pengabdian dalam bentuk pemicuan dan pengontrolan selama tiga bulan mampu membentuk perilaku pencegahan diabetes mellitus pada kelompok prediabetes. Saran kepada aparatur gampong, warga, dan petugas kesehatan untuk dapat melakukan pengabdian serupa secara simultan pada kelompok prediabetes untuk membentuk dan menjaga pola perilaku pencegahan diabetes mellitus.
\end{abstract}

Kata Kunci : Pola Makan, Olahraga, dan Prediabetes.

\section{PENDAHULUAN}

\section{Analisis Situasi}

Peningkatan kasus diabetes mellitus (DM) dapat dicegah dengan mengetahui kelompok risiko tinggi DM yaitu Prediabetes. Prediabetes meupakan kelompok TGT (Toleransi Glukosa Terganggu) dan yang diduga berdasarkan gejala dapat dikategorikan berdasarkan kadar glukosa darah (140-199mg/dl). Pemahaman secara cepat terkait kelompok risiko tinggi DM mampu membawa kita kepada upaya pencegahan dalam bentuk pola makan yang benar dan olahraga teratur. Di Indonesia berdasarkan data 
Riskesdas 2013 diperkirakan proporsi TGT (Toleransi Glukosa Terganggu : 140$199 \mathrm{mg} / \mathrm{dl}$ ) sebesar $29,9 \%$ atau 52 juta kasus dan bisa saja meningkat setaip tahunnya (Kemenkes RI, 2014).

Di Kabupaten Aceh Barat berdasarkan data yang dilaporkan oleh Dinas Kesehatan Kabupaten Aceh Barat menunjukkan angka penderita diabetes mellitus terus meningkat setiap tahunnya. Dari data tahun 2014 menunjukkan bahwa prevalensi kasus diabetes mellitus yang dilaporkan sebanyak $1.29 \%$. Pada tahun 2015 prevalensi kasus diabetes mellitus meningkat menjadi $1.02 \%$. Pada tahun 2016 prevalensi kasus diabetes mellitus kembali meningkat menjadi $1.65 \%$. Pada tahun 2017 prevalensi kasus diabetes mellitus kembali meningkat menjadi 1.96\% (Profil Dinas Kesehatan Kabupaten Aceh Barat, 2017).

Berdasarkan data dari RSUD Cut Nyak Dhien Meulaboh data kasus DM terus meningkat setiap tahunnya dapat kita lihat pada tren kasus pertahun berikut ini : tahun 2014 terdapat 295 kasus dan tahun 2015 terdapat 783 kasus, tahun 2016 terdapat 850 kasus, tahun 2017 terdapat 980 kasus. Berdasarkan data dari setiap Puskesmas Tahun 2018 yaitu Puskesmas Johan Pahlawan, Suak Ribe, Meureubo, Peureumeu Arongan Lambalek, Kaway XVI DM selalu menempati 10 penyakit PTM terbanyak, dan terutama yang menyumbang adalah daerah perkotaan. Gampong Kampung Belakang merupakan salah satu kampung yang menjadi wilayah kerja puskesmas johan pahlawan yang terletak di daerah perkotaan yang merupakan penyumbang salah satu kasus DM terbanyak di Puskesmas Johan Pahlawan dan RSUD Cut Nyak Dhien Meulaboh. Berdasarkan hasil survey awal (Putri, dan Is, 2017) Gampoeng Kampung
Belakang termasuk daerah perkotaan banyak dijumpai (40\%) seseorang berada pada kelompok prediabetes tetapi tidak mengetahuinya disebabkan oleh gaya hidup (pola makan dan olahraga yang tidak sehat).

Berdasarkan latar belakang ini maka perlu adanya bentuk jasa pelayanan dalam bentuk implementasi model pola makan dan olahraga pada kelompok prediabetes sehingga dapat mencegah kasus DM.

\section{Rincian Permasalahan}

Dalam mewujudkan implementasi tersebut, maka pengusul merincikan permasalahan di Gampoeng Kampung Belakang berdasarkan survei awal sebagai berikut:

1. Masih kurangnya pemahaman masyarakat terkait kelompok risiko tinggi DM (prediabetes), sehingga dapat berdampak pada peningkatan kasus DM.

2. Masih kurangnya pemahaman masyarakat terhadap menu diet anti DM dalam pengelolaan pola makan, sehingga mampu mencegah penyakit DM.

3. Masih kurangnya pemahaman masayarakat terhadap olahraga yang benar dan teratur yang mampu mencegah penyakit DM.

\section{Solusi Permasalahan}

Solusi yang pengusul tawarkan dalam mengatasi beberapa maslah diatas adalah sebagai berikut:

1. Memberikan sosialisasi kepada kelompok prediabetes (kelompok prediabetes mawar (10 orang) dan kelompok prediabetes melati (10 orang)) dalam bentuk pemberian menu diet anti diabetes dan demo masak (pengolahan makanan) yang diawali dari pemilihan hingga penyajian bahan makanan berdasarkan menu diet yang 
telah berhasil diuji melalui penelitian yang mampu menurunkan kadar gula darah.

2. Memberikan pemicuan dan pendampingan kepada kelompok prediabetes yaitu (kelompok prediabetes mawar (10 orang) dan kelompok prediabetes melati (10 orang)) selama 3 (tiga) bulan dalam menjaga pola makan dan olahraga agar tetap sesuai dengan model yang telah diberikan.
3. Pengontrolan dalam bentuk pemeriksaan melalui grup whatsup dalam bentuk pengiriman dokumentasi serta pertemuan rutin selama tiga bulan masa implementasi model pola makan dan olahraga pada kelompok prediabetes (kelompok prediabetes mawar (10 orang) dan kelompok prediabetes melati (10 orang)) sehingga model tersebut dapat benarbenar berhasil membentuk kebiasaan masyarakat dan mencegah DM.

\section{METODE PELAKSANAAN}

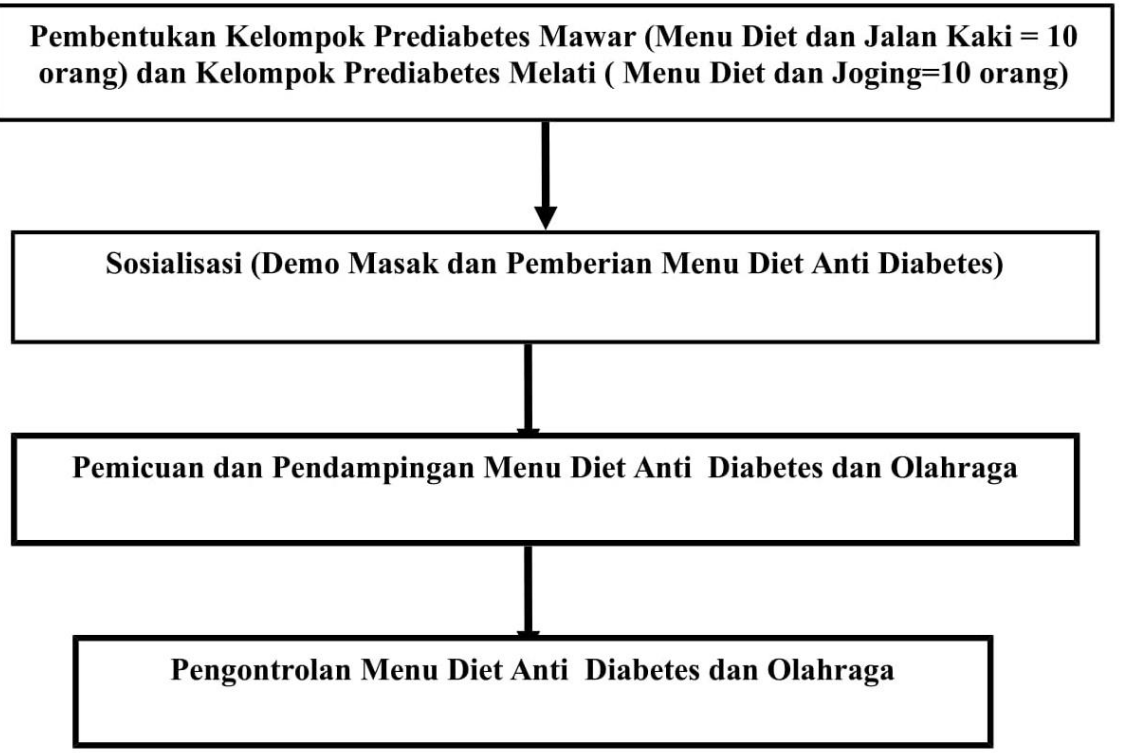

Gambar 1. Bagan Alir Metode Pelaksanaan

a. Pembentukan Kelompok

Prediabetes

Pada pengabdian pengusul membentuk dua kelompok prediabetes yaitu kelompok prediabetes mawar (10 orang) dan kelompok prediabetes melati (10 orang). Kedua kelompok (Prediabetes mawar (10 orang) dan Prediabetes Melati (10 orang)) pada tahap pengabdian awal sama-sama diberikan sosialisasi berupa demo masak diet prediabetes dan pemberian model menu diet dan olahraga.

Pada tahap pengabdian berikutnya yaitu intervensi model pola makan dan olahraga prediabetes terdapat perbedaan perlakuan yaitu pada kelompok prediabetes mawar diberikan menu diet prediabetes yang akan diterapkan selama 3 bulan tetapi jenis olahraga adalah jalan santai $(3 \times 30$ menit seminggu selama 3 bulan), sedangkan pada kelompok prediabetes melati menu diet tetap sama dan dilaksanakan selama 3 bulan tetapi perbedaannya adalah pada jenis olahraga yaitu joging (lari-lari kecil) (3x30 menit seminggu selama 3 bulan). 
Penjelasan diatas dapat pengusul kelompokkan dalam Tabel 1. Sebagai berikut :

Tabel 1. Rincian Intervensi Kelompok

\begin{tabular}{|l|l|}
\hline Kelompok & Intervensi \\
\hline $\begin{array}{l}\text { Prediabetes } \\
\text { Mawar }\end{array}$ & $\begin{array}{l}\text { Menu Diet (3 bulan) dan } \\
\text { jalan santai (3x30 menit } \\
\text { seminggu selama 3 bulan) }\end{array}$ \\
\hline $\begin{array}{l}\text { Prediabetes } \\
\text { Melati }\end{array}$ & $\begin{array}{l}\text { Menu Diet (3 bulan) dan } \\
\text { joging (lari-lari kecil) (3x } \\
\text { 30menit seminggu selama } \\
3 \text { bulan) }\end{array}$ \\
\hline
\end{tabular}

b. Pengbdian Tahap Awal

Pada pengabdian tahap awal pengusul melaksanakan intervensi pengabdaian untuk kedua kelompok yang berjumlah 20 orang dengan bentuk pengabdian yaitu sosialasi (demo masak prediabetes) dan pemberian menu diet prediabetes.

Pada demo masak pengusul akan menjelaskan cara pengolahan makanan

\section{HASIL DAN PEMBAHASAN}

Tahap Awal Pengabdian (Pembagian Dua Kelompok Prediabetes)

Berdasarkan hasil pengabdian tahap awal telah terbentuk dua kelompok yaitu kelompok prediabetes mawar (perlakuan pemberian menu diet anti diabetes ditambah jalan santai) dan kelompok prediabetes melati (perlakuan pemberian menu diet anti diabetes berdasarkan menu diet prediabetes yang diawali dengan pemilihan bahan makanan sampai penyajian menu makanan.

c. Pengabdian Tahap Berikutnya

Pada pengbdian tahap berikutnya dilakukan pemicuan dan pendampingan setiap kelompok (prediabetes mawar dan prediabetes melati) telah mulai dan sedang melaksanakan model pola makan dan olahraga prediabetes. Pada pelaksanaan yang dilkukan oleh setiap kelompok akan dipantau dan dikontrol oleh tim pelaksana pengabdian setiap harinya dan wajib mengirimkan bukti pelaksanaan ke grup wa yang dibuat tim dalam bentuk gambar setiap minggunya selama 3 (tiga) bulan.

d. Penilaian Hasil Akhir Pengabdian Penilaian hasil akhir adalah kepatuhan atas pemicuan dan pendampingan yang diberikan dengan bukti kelengkapan dokumentasi pelaksanaan menu diet dan olahraga.

ditambah lari-lari kecil) dengan jumlah total 20 (dua puluh) orang.

Tahap Kedua Sosialisasi Demo Masak dan Pemberian Menu Diet Anti Diabetes

Pada tahap berikutnya kedua kelompok mengikuti demo masak dan pemberian menu diet dan demo masak. 

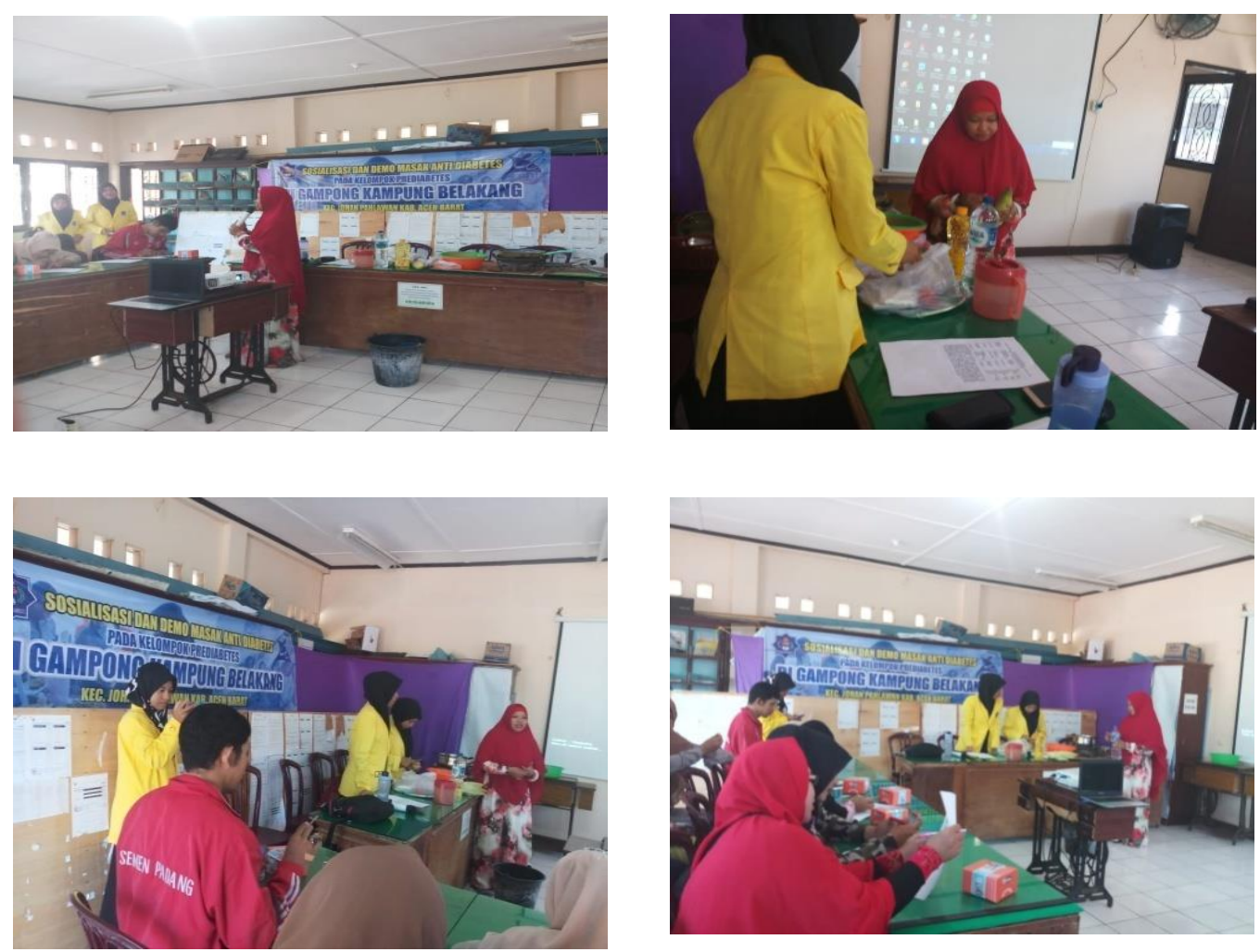

Gambar 1. Sosialisasi Demo Masak dan Pemberian Menu Diet Anti Diabetes

Hasil sosialisasi dalam bentuk demo masak dan pemberian menu diet yang telah diuji berdasrkan hasil penelitian (Putri dan Is, 2017) mendapatkan tanggapan yang baik dari kelompok prediabetes yang telah dibentuk (kelompok mawar dan melati), terlihat bahawa kelompok prediabetes hadir pada acara. Pada saat diskusi mereka mengajukan pertanyaan kepada pemateri (Enda Silvia Putri, SKM, M.Kes) terkait bagaimana sebaiknya lama waktu memasak sayuran dan juga terkait teknis penerapan menu diet anti diabetes yang telah dibagiakan.
Hasil sosialisasi tahap awal ini dapat disimpulkan bahwa 90\% kelompok antusias melaksanakan menu diet anti diabetes dan olahraga.

Tahap Ketiga Pemicuan Dan Pengontrolan Pola Makan dan Olahraga

Pada tahapan ini perlakuan dalam bentuk pemicuan dan pengontrolan dilakukan untuk mengevaluasi pelaksanaan perilaku hidup sehat dalam bentuk implementasi pola makan dan olahraga pada kelompok prediabetes mawar dan kelompok prediabetes melati. 

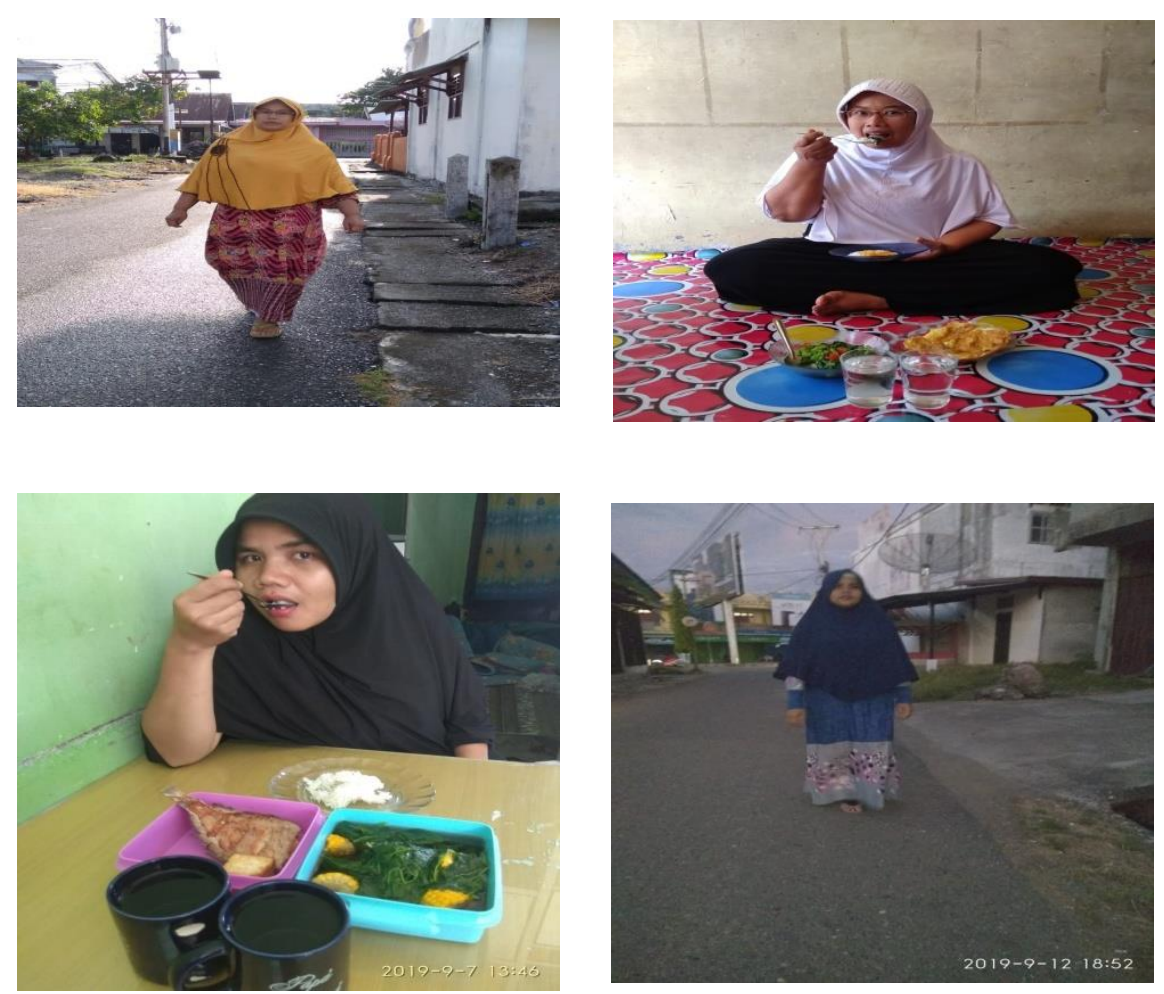

Gambar 2. Implementasi Pola Makan dan Olahraga Pada Kelompok Prediabetes Mawar

Hasil pelaksanan tahap ketiga terlihat pada gambar 2. yang merupakan sampel responden kelompok prediabetes mawar. Berdasarkan upaya pemicuan dan pengontrolan yang kami lakukan melalui grup whatsup dan kunjungan langsung kepada 10 (sepuluh) orang responden kelompok prediabetes mawar diperoleh bahwa tingkat kepatuhan pelaksanan dari hasil dokumentasi yang dikumpulkan maka diperoleh persen sebesar $75 \%$ tingkat kepatuhan. Kelompok prediabetes mawar melaksanakan imlpementasi pola makan berdasarkan menu diet selama 3 (tiga) bulan dan olahraga dalam bentuk jalan santai 3x seminggu selama 30 menit sehingga total olahraga 36 kali dalam 3 bulan. Tingkat kepatuhan memperoleh nilai $70 \%$ dikarenakan jumlah responden yang lengkap dokumentasi dan mengikuti sesuai pemicuan 7 responden sedangkan 3 responden dokumentasi kurang lengkap dan kurang mengikuti sesuai pemicuan. 

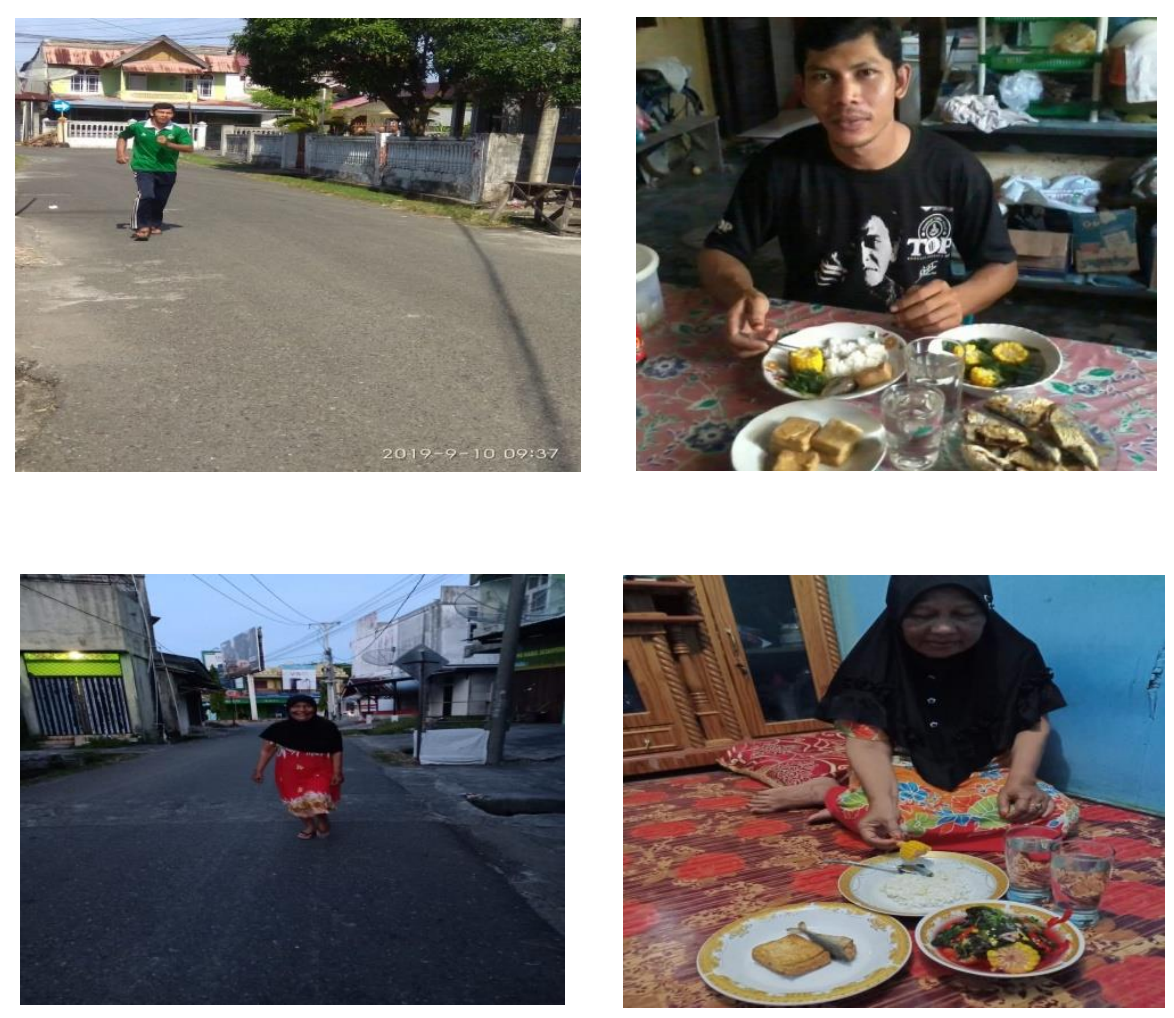

Gambar 3. Implementasi Pola Makan dan Olahraga Pada Kelompok Prediabetes Melati

Hasil pelaksanan pada tahapan pemicuan dan pengontrolan terlihat pada gambar.3 yang merupakan sampel responden kelompok prediabetes melati. Berdasarkan upaya pemicuan dan pengontrolan yang kami lakukan melalui kunjungan langsung dan pengiriman pesan melalui grup wahtsup kepada 10 responden kelompok prediabetes melati. Berdasarkah hasil evaluasi terlihat bahwa tingkat kepatuhan mencapai $90 \%$, nilai tersebut diperoleh dari penilaian kelengkapan dokumentasi yang dikumpulkan dan terlaksananya perilaku sesuai pemicuan yang diarahkan. Dari 10 responden 9 melakukan secara tepat sedangkan 1 orang kurang tepat. Kelompok prediabetes melati telah melakukan pelaksanaan menu diet anti diabetes dan olahraga dalam bentuk lari-lari kecil. Hasil evaluasi secara menyuluruh terlihat bahwa kelompok prediabetes melati kepatuhan lebih baik dan semangat dibandingakan kelompok prediabetes mawar.

Berdasarkan hasil pengabdian diperoleh bahwa perilaku implementasi pola makan dan olahraga telah dilakukan dengan tepat sehingga mampu mencegah diabetes pada kelompok prediabetes, karena berdasarkan rata-rata kepatuhan dari kedua kelompok adalah $80 \%$. 


\section{KESIMPULAN}

Berdasarkan hasil pengabdian yang telah dialaksanakan, maka diperoleh kesimpulan sebagai berikut :

1. Implementasi pola makan dengan kepatuhan $80 \%$ mampu mencegah diabetes pada kelompok prediabetes.

2. Implementasi olahraga secara terartur dengan kepatuhan $80 \%$

\section{SARAN}

Berdasarkan hasil pengabdian yang telah dialaksanakan, maka diharapkan saran sebagai berikut :

1. Pengabdian dalam bentuk implementasi pola makan dan olahraga dapat diteruskan oleh pihak aparatur gampung malalui program gampung melihat hasil pengabdaian ini memberikan dampak positif terhadap warga.

2. Pengabdian dalam bentuk implementasi pola makan dan olahraga dapat diteruskan oleh pihak aparatur gampung malalui kerjasama dengan perguruan tinggi (seperti FKM-UTU), Puskesmas,

\section{UCAPAN TERIMAKASIH}

Ucapan terimakasih atas terlaksanya pengabdian ini kami persembahkan kepada:

1. Bapak Rektor Universitas Teuku Umar: Bapak Prof. Jasman J. Ma'ruf, MBA

2. Bapak Dekan Fakultas Kesehatan Masyarakat-Universitas Teuku Umar : Bapak Prof. Dr. drh. Darmawi, M.Si

3. Bapak Ketua Lembaga Penelitian dan Pengabdian Masyarakat dan mampu mencegah diabetes pada kelompok prediabetes

3. Pemicuan dan pengontrolan yang rutin mampu mengubah perilaku dan membentuk kepatuhan kelompok terhadapa pola makan dan olahraga yang mampu mencegah diabetes.

dan instansi lain yang terkait melihat hasil pengabdaian ini memberikan dampak positif terhadap warga.

3. Pengabdian dalam bentuk implementasi pola makan dan olahraga dapat diteruskan oleh pihak aparatur gampung malalui pemicuan dan pengontrolan rutin melalui kerjasama dengan perguruan tinggi (seperti FKMUTU), Puskesmas, dan instansi lain yang terkait melihat hasil pengabdian ini memberikan dampak positif terhadap warga.

Penjaminan Mutu (LPPM-PM) Universitas Teuku Umar: Bapak Ir. Rusdi Faizin, MP dan Para Stru ktural dan Staf LPPM-PM

4. Bapak Geucik Gampoeng Kampung Belakang Bapak Efrizal Idrus, ST

5. Aparatur Gampoeng Kampung Belakang

6. Masyarakat Gampoeng Kampung Belakang 


\section{REFERENSI}

Bustan, M.N. 2015. Manajemen Pengendalian Penyakit Tidak Menular. Jakarta : Rineka Cipta.

Jansje H, V. Ticoalu \& Yoseph L Samodra. 2012. Penyakit Tidak Menular. Jakarta : Rineka Cipta.

Kemenkes RI. 2014. InfoDATIN Diabetes : "Situasi dan Analisis Diabetes". Jakarta Selatan : Badan Penelitian dan Pengembangan Kesehatan, Departemen Kesehatan, Republik Indonesia.

Laporan Puskesmas Johan Pahlawan. 2018. Data Kesehatan Diabetes Melitus. Aceh

Putri, ES., dan Is, JM. 2017. Strategi Penyuluhan Dalam Meningkatkan Pengetahuan Pencegahan DM. Jurnal Kesehatan Masyarakat: VOLUME IV/ NOMOR 7/ 2017/HAL 156 163, ISSN: 23550643.

Putri, ES., dan Is, JM. 2017. Strategi Promosi Kesahatan Dalam Upaya Penurunan Kasus DM di Aceh Barat. Laporan Akhir Pengabdian Dosen Pemula Tahun 2017.

Profil Kesehatan Aceh. 2015. Data Kesehatan Diabetes Melitus di Aceh. Aceh

Profil Dinkes Aceh Barat. 2017. Data Kesehatan Diabetes Melitus. Aceh Barat.

Riskesedas. 2013. Riset Kesehatan Dasar Badan Penelitian Dan Pengembangan Kesehatan Kementerian Kesehatan Ri Tahun 2013

World Health Organization . 2012. Diabetes. World Health Organization. 